\title{
Varakult haridussüsteemist lahkumine: trendid, mõjurid ja meetmed Eestis
}

\author{
Kadri Kallip ${ }^{\text {1a }}$, Mati Heidmets ${ }^{\mathrm{a}}$ \\ ${ }^{a}$ Tallinna Ülikooli haridusteaduste instituut
}

\begin{abstract}
Annotatsioon
Varakult haridussüsteemist lahkunud noorte puhul on tegemist õpinguid mittejätkavate 18-24aastaste noortega, kellel on põhiharidus või sellest madalam haridustase. Kuigi nende hulk Eestis näitab viimasel kümnendil vähenemistendentsi, on varakult haridussüsteemist lahkunud noori jätkuvalt liiga palju. Nende osakaal Eestis on ka vähenenud aeglasemalt kui enamikus teistes Euroopa Liidu (EL) riikides. Artikli eesmärk on anda ülevaade varakult haridussüsteemist lahkumise trendidest Eestis ajavahemikul 2000-2015 ja kirjeldada haridustee katkestamise peamisi mõjureid ning ennetus-, sekkumis- ja tagasitoomismeetmeid. Andmete metaanalüüs tugineb nii Eesti ja ELi statistikaameti (Eurostati) tööjõu-uuringute andmetele kui ka Eesti hariduse infosüsteemi (EHIS) ning Eesti statistikaameti andmebaasidele. Tulemused näitavad, et Eestis on varakult haridussüsteemist lahkunud isikute seas suur noormeeste osakaal ning peamisteks haridustee katkestamise riskiteguriteks võib pidada nii maa-asulas elamist kui ka muu riigi kodakondsuse omamist. Lisaks ilmneb, et põhiharidusega või sellest madalama haridusega piirdunud 18-24aastased noored elavad võrreldes oma eakaaslastega, kellel on kõrgem haridustase, suuremas sotsiaalse tõrjutuse või vaesusohus, kogevad enam suhtelist ja absoluutset vaesust ning materiaalset ilmajäetust ja osalevad vähem tööturul. Samuti selgub artiklist, et kuigi Eestis ei ole varakult haridussüsteemist lahkunud noorte sihtrühmale välja töötatud eriprogramme, on nii riikliku, kohaliku omavalitsuse kui ka kooli tasandil olemas üleüldisi meetmeid ja teenuseid, mida kasutatakse haridustee katkestamise ohus õpilaste aitamiseks.
\end{abstract}

Võtmesõnad: varakult haridussüsteemist lahkumine, õpingute katkestamine, meetmed, sotsiaaldemograafia, rahvusvaheline võrdlus, elukestev õpe 


\section{Sissejuhatus}

Mõistet varakult haridussüsteemist lahkumine kasutatakse ELis ametlikult 18-24aastaste noorte puhul, kellel on põhiharidus või on see lõpetamata ja kes ei jätka õpinguid ega osale koolitustel. Sealjuures peetakse gümnaasiumis või kutsekoolis omandatud keskharidust miinimumnõudeks, et tagada edasiõppimisvõimalused ning edukas üleminek haridusvaldkonnast tööturule (OECD, 2016). Hinnanguliselt puudutab varakult haridussüsteemist lahkumine ELis üle 4 miljonit noort, kellest ligikaudu 60\% kuulub mitteaktiivsete või töötute hulka (Eurostat, 2016) ja umbkaudu 30\% elab sotsiaalse tõrjutuse või vaesusohus (Eurostat, 2017). Eri riikide kogemused on näidanud, et varakult haridussüsteemist lahkunud isikud on suurema tõenäosusega töötud kui need, kes on omandanud keskhariduse.

Majanduslike, tehnoloogiliste ja sotsiaalsete muutuste taustal kujunevad tööülesanded varasemast komplitseeritumaks, mistõttu kasvab nõudlus ka kõrgema haridustasemega ning suuremate oskustega tööjõu järele. Kuigi kõik noored on pidanud kohanema nii hariduses kui ka tööturul aset leidnud muutustega, siis mitte kõigil ei ole õnnestunud edukalt kas ühelt haridusastmelt teisele või haridusvaldkonnast tööturule siirduda. Varakult haridussüsteemist lahkunud noorte puhul on tegemist sihtrühmaga, kes kogeb enim takistusi nii haridusvaldkonnast tööturule, ühelt haridusastmelt teisele (Rumberger \& Lamb, 2003) kui ka ühest koolist teise üleminekul. Kui veel mõnikümmend aastat tagasi olid noorte eluteed ettearvatavad ja sirgjoonelised, siis tänapäeval on üleminekud kogu Euroopas muutunud väga keeruliseks (Côté, 2000). Lisaks võib oletada, et need haridusasutused, mis on olnud avatud, paindlikud ja käinud muutustega kaasas, on suutnud arvestada keskmisest enam õpilaste huvide ja vajadustega ning reageerida ühiskonnas aset leidvatele muutustele.

Kuigi enne keskhariduse omandamist haridustee katkestanud noorte arv on enamikus liikmesriikides viimase kümnendi jooksul järjepidevalt vähenenud (Eurostat, 2017), on teema jätkuvalt aktuaalne. Varakult haridussüsteemist lahkumise osakaalu vähendamine aastaks 2020 alla 10\% on üks Euroopa 2020. aasta strateegia eesmärkidest ja üks viiest sihttasemest ELi haridusstrateegias „Haridus ja koolitus 2020“ (European Commission, 2011). Seega võib väita, et keskharidust mitteomandanud noorte arvu vähendamine on kogu Euroopa hariduspoliitika prioriteet. Eesti on seadnud eesmärgiks vähendada 2020. aastaks madala haridustasemega 18-24aastaste mitteõppivate noorte 
osakaalu 9,5\%ni (Vabariigi Valitsus, 2013). 2015. aastal oli Eestis varakult haridussüsteemist lahkunud noori 11,2\% ning 2014. aastal oli see näitaja 11,4\% ${ }^{2}$.

Varakult haridussüsteemist lahkumist käsitledes on Eestis varem keskendutud peamiselt üldharidus- või kutsekoolist väljalangemise negatiivsetele tagajärgedele ja riskitegurite väljaselgitamisele, mitte niivõrd laiema pildi loomisele haridussüsteemist lahkumise kohta. Kuna puudub terviklik ja ajakohane ülevaade varakult haridussüsteemist lahkunud noortest, siis sellest tulenevalt on artikli eesmärk kirjeldada varakult haridussüsteemist lahkumise üldisi trende Eestis ajavahemikul 2000-2015 ning anda ülevaade varakult haridussüsteemist lahkumise peamistest mõjuritest ja ennetus-, sekkumis- ja tagasitoomismeetmetest võrdluses teiste ELi riikidega. Artiklis esitatud analüüs toetub Statistikaameti ja Eurostati tööjõu-uuringute ning EHISe andmetele. Sealjuures ei ole autorid teinud täiendavat andmeanalüüsi, vaid on kasutanud Statistikaameti, EHISe ja Eurostati andmebaasides esitatud andmeid.

\section{Haridustee katkestamine: terminoloogia}

Eestis on haridustee varajase katkestamise kohta kasutusel eri terminid. Sageli käsitatakse nii ametlikult kui ka mitteametlikult sünonüümidena termineid kooli poolelijätnu, õppetöö katkestaja, öpingute katkestaja, koolist väljalangenu, madala haridustasemega isik ja varakult haridussüsteemist lahkunud noor (vt joonis 1). Siiski on neil oskussõnadel eri tähendus.

Kõige täpsemalt piiritletud sisuga termin on varakult haridussüsteemist lahkumine. Varakult haridussüsteemist lahkunud isikuteks peetakse neid 18-24aastaseid noori, kes on haridustee katkestanud kas enne põhihariduse omandamist, pärast põhikooli lõpetamist või keskhariduse omandamise käigus. Seega loetakse varakult haridussüsteemist lahkunud noorte hulka nii mõne klassi haridusega isikud kui ka need, kellel on haridustee katkenud alles keskkooli viimases klassis. Eurostati tööjõu-uuringus liigitatakse varakult haridussüsteemist lahkunud noorteks need, kes õppisid üldharidus- ja/või kutsekoolis ning ei osalenud õppetöös või koolitusel ELi tööjõu-uuringule eelnenud nelja nädala jooksul. Eestis saadakse varakult haridussüsteemist lahkunud isikute kohta statistilist infot Statistikaameti Eesti tööjõu-uuringu (ETU) kaudu. Sealjuures kogub Statistikaamet infot kalendriaastate kaupa, võimalik ei

Artiklis tuginetakse statistilise informatsiooni esitamisel peamiselt Eurostati tööjõu-uuringu andmetele, kus üldkogumisse on arvestatud kõik Eestis elavad tööealised isikud, v.a need, kes viibisid institutsioonides (hooldekodudes, vanglates vm). Kuna aluseks võetakse ka statistikaameti ETU andmed, kus üldkogumisse kuuluvad kõik Eestis elavad tööealised isikud, siis esinevad kahe tööjõu-uuringu statistiliste näitajate puhul mõningad erinevused. 
ole eristada üld- ja kutsehariduse kohta käivaid andmeid ning statistika hõlmab kõiki 18-24aastaseid isikuid.
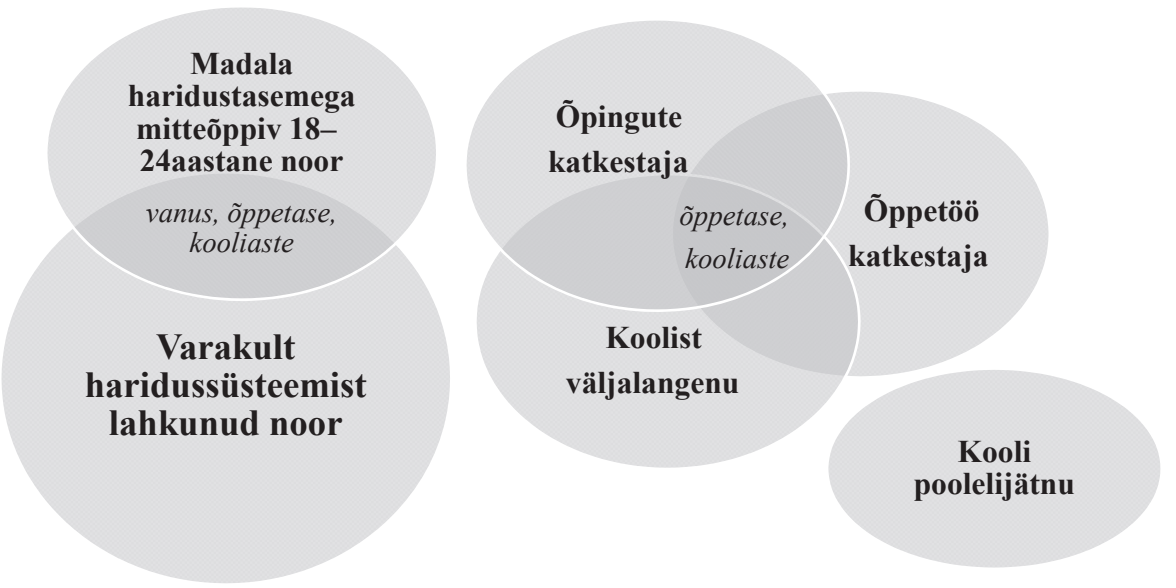

Joonis 1. Haridustee katkestamise terminoloogia ühisosa järgi

Rõhutamist väärib asjaolu, et varakult haridussüsteemist lahkumine ei tähenda ilmtingimata koolist väljalangemist. Paljud Eesti noored ei jätka pärast põhikooli lõpetamist haridusteed. EHISe (2017a) andmed näitavad, et alates 2009. aastast on olnud igal aastal põhikooli lõpetajatest vähemalt 3\% neid noori, kes ei jätka õpingutega samal aastal või on täielikult loobunud edasisest õppimisest järgmises haridusastmes. Lisaks on termin varakult haridussüsteemist lahkumine toortõlge ingliskeelsest sõnaühendist early school leaving, mille asemel kasutatakse nüüdseks terminit early leavers from education and training. Kuigi Eesti Keele Instituut on välja pakkunud ka omakeelse termini ópiseiskur, ei ole seda laiemalt kasutusele võetud.

Madal haridustase on neil isikutel, kellel on põhiharidus või sellest madalam haridustase. Seega võib seda terminit kasutada igas vanuses inimese kohta. Kui on täpsustatud, et mitteõppiv isik kuulub 18-24aastaste vanuserühma, siis on tegemist varakult haridussüsteemist lahkunud noore vastega. Termineid väljalangenu, koolist väljalangenu, õppetöö katkestaja ja õpingute katkestaja kasutatakse nende õpilaste puhul, kes on mis tahes põhjusel katkestanud õpingud kas põhi-, kesk- või kõrghariduse tasandil. Õppetöö katkestajate kohta peetakse arvet EHISes, kus võetakse arvesse neid õpilasi, kes arvatakse kooli nimekirjast välja õppeaasta jooksul (sõltumata õppevormist) ja kes ei lõpeta ega jätka õpinguid järgmise õppeaasta 10. novembriks. Seega kogutakse andmeid õppeaasta kohta ning üld- ja kutsehariduse andmeid käsitletakse eraldi. Sealjuures võis õpilane õppida üldhariduskoolis või kutseõppeasutuses. Kuna Statistikaameti 
andmed õpilaste ja õpingute katkestajate kohta on kalendriaastate arvestuses, siis esinevad mõningad erinevused EHISe ja Statistikaameti andmetes.

Terminit kooli poolelijätmine kasutatakse sageli ELi ametlike dokumentide tõlgetes varakult haridussüsteemist lahkumise sünonüümina. Kuna varakult haridussüsteemist lahkumise puhul ei ole alati tegemist kooli poolelijätmisega, siis on nende terminite sünonüümne kasutus ebatäpne. Oskussõna kooli poolelijätmine on asjakohane kasutada koolist väljalangemise ja ópingute katkestamise sünonüümina.

Võttes arvesse nii erinevusi statistiliste andmete kogumisel kui ka haridustee katkestamist märkivate terminite tähendusi, siis võib öelda, et termini varakult haridussüsteemist lahkunud noor sünonüümidena pole õige kasutada termineid õpingute katkestaja, koolist väljalangenu ega kooli poolelijätnu. Sobivaimaks vasteks on madala haridustasemega mitteõppiv 18-24aastane noor.

Eestis on hariduspoliitika oluline eesmärk vähendada madala haridustasemega mitteõppivate 18-24aastaste noorte osakaalu. Kuigi varakult haridussüsteemist lahkunud isikute kohta kogutavad statistilised andmed võimaldavad võrrelda eri liikmesriikide edukust nende osakaalu vähendamisel, ei ole aga muutusi riiklikul tasandil võimalik piisavalt seirata. Tööjõu-uuringud annavad infot ainult kõrgeima omandatud haridustaseme kohta. Samas ei sisalda need teavet, kas noor õppis üldharidus- või kutsekoolis ning millises kooliastmes ja klassis õpingud katkestati. Samuti puudub info selle kohta, kas noor alustas pärast haridustee katkestamist uuesti õpingutega ja kui edukas ta nendes oli. Seega ei võimalda varakult haridussüsteemist lahkunud noori puudutavad statistilised andmed saada ülevaadet noorte haridustee valikutest Eestis. Samal ajal on teada, et paljud teised liikmesriigid koguvad varakult haridussüsteemist lahkunud noorte haridustee kohta spetsiifilisemaid andmeid (European Commission, EACEA, Eurydice, \& Cedefop, 2014). Ka ei ole võimalik varakult haridussüsteemist lahkunud isikute puhul teada saada infot vanemate haridustaseme ja perekonna sotsiaal-majandusliku tausta kohta. Täpsem info varakult haridussüsteemist lahkunud isikute trajektooride kohta võimaldaks aga välja töötada õigeaegsed ja sihipärased tugimeetmed (Cedefop, 2016), ent ka hinnata sekkumisviiside tõhusust. Noored, kes piirduvad ainult põhiharidusega, vajavad teistsugust tuge haridusvaldkonda tagasipöördumiseks kui need, kes ebaõnnestuvad keskkooli lõpueksamitel. Märkimisväärne on ka asjaolu, et neid noori, kes osalesid tööjõu-uuringule eelnenud nelja nädala jooksul mistahes kvaliteedi, mahu ja sisuga koolitusel, ei arvestata varakult haridussüsteemist lahkunud noorte hulka. Seega võib väita, et tegelikult on varakult haridussüsteemist lahkunud noori rohkem, kui tööjõu-uuringute andmed näitavad (Kaye, D’Angelo, Ryan, \& Lőrinc, 2014). 


\section{Olukord Eestis}

Alates 2010. aastast on Eestis varakult haridussüsteemist lahkunud noori varasemate aastatega võrreldes oluliselt vähemaks jäänud (vt joonis 2). Kui aastatel 2000-2009 oli nende osakaal vahemikus 13,6-15,1\%, siis alates 2010. aastast on haridustee katkestanute arv selgelt vähenenud, jäädes vahemikku 9,7-11,4\% (Eurostat, 2017). 2015. aastal oli põhiharidusega või sellest madalama haridusega õpinguid mittejätkavaid 18-24aastaseid noori ligikaudu 12000.

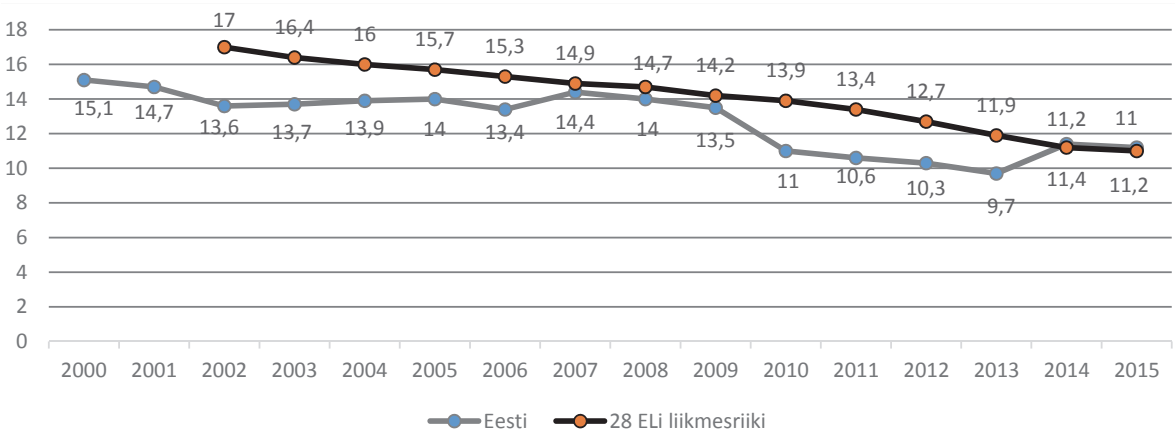

Joonis 2. Varakult haridussüsteemist lahkunud noored Eestis aastatel 2000-2015 (osatähtsus 18-24aastaste hulgas \%, Eurostat, 2017, tesem020)

Siinjuures tasub märkida, et 2010. aasta alguses võeti vastu strateegia „Euroopa 2020“, mille raames hakati suuremat tähelepanu pöörama just varakult haridussüsteemist lahkunud noorte temaatikale. Samuti jääb 2010. aasta ajalukku kui kõige suurema tööpuudusega ja väikseima tööhõivega aasta (Sotsiaalministeerium, 2012). Samal perioodil suurenes ka osalus kutsehariduses (EHIS, 2017a). Rõhutamist väärib veel asjaolu, et kuna tööjõu-uuringu andmeid on kogutud valimipõhiselt, siis üksikute aastate jooksul toimunud muutuste kohta ei saa teha suuremaid üldistusi.

Eurostati andmetest selgub, et 2013. aastal oli varakult haridussüsteemist lahkunud noori Eestis 9,7\%, mis oli ligilähedane eesmärgiks seatud 9,5\%-le. Samas suurenes nende osakaal 2014. aastaks 11,4\%-ni ning vähenes järgmisel aastal 0,2\%. Sealjuures oli Eesti 2015. aasta näitaja kehvem 20 liikmesriigi omast. Lisaks näitavad andmed, et kui varakult haridussüsteemist lahkunute osakaal Eestis on olnud aastate jooksul ELi riikide keskmisest enamasti oluliselt väiksem (vahe 1,7-3,4\%), välja arvatud aastatel 2007-2009, kus Eesti näit oli liikmesriikide keskmisest mõnevõrra väiksem (vahe 0,5-0,7\%), siis alates 2014. aastast on Eesti näit olnud ELi keskmisega sarnasel tasemel. 
Kui varasematel aastatel kuulus Eesti varakult haridussüsteemist lahkumise keskmise osakaaluga ELi riikide sekka (BE, DK, DE, IE, FR, LV, HU, NL, AT ja FI), siis alates 2014. aastast on Eesti näitaja võrreldav Hispaania, Itaalia, Bulgaaria, Malta, Rumeenia ja Portugali omaga. Tegemist on riikidega, kus on alati olnud enim varakult haridussüsteemist lahkunud noori (vt joonis 3). Samas on alates 2010. aastast varakult haridussüsteemist lahkumise osakaal vähenenud Portugalis ja Hispaanias üle 8\%, Maltal üle 4\% ning Itaalias üle 3\%. Rumeenias, Bulgaarias ja Eestis on samal ajavahemikul muutused aset leidnud $+/-0,5 \%$ piires. Tuginedes Eurostati andmetele, võib öelda, et Eestis on varakult haridussüsteemist lahkunud noorte osakaal vähenenud aeglasemalt kui paljudes teistes liikmesriikides.

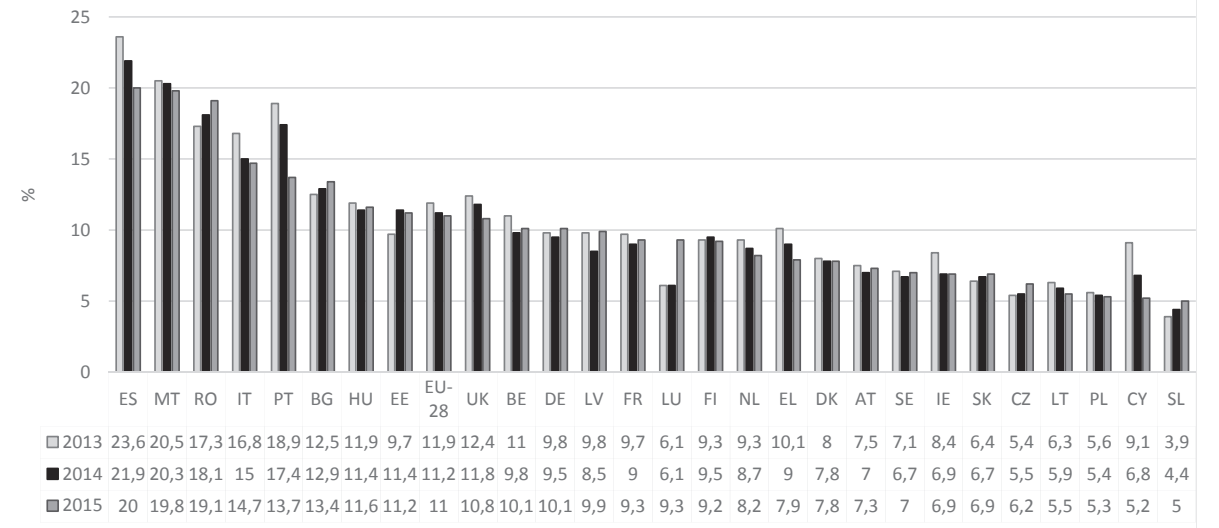

Joonis 3. Varakult haridussüsteemist lahkunud 18-24aastased noored ELis 20132015. aastal (osatähtsus 18-24aastaste hulgas \%, Eurostat, 2017)

Eurostati andmed näitavad, et 2015. aastal oli liikmesriikides varakult haridussüsteemist lahkunuid vahemikus 2,8\% (Horvaatia) kuni 20\% (Hispaania). Kusjuures 2010. aastaga võrreldes on ELi riikides varakult haridussüsteemist lahkunud noorte keskmine osakaal kuue aastaga vähenenud 2,9\% (Eurostat, 2017). Eestis on samadel aastatel jäänud varakult haridussüsteemist lahkunud noorte osakaal samale tasemele, kus võrreldes 2010. aasta 11\%-lt tõusis näit 11,2\%-ni.

Eurostati ja Statistikaameti tööjõu-uuringute andmed ei võimalda varakult haridussüsteemist lahkunud noorte puhul eraldi välja tuua osakaale üldharidus- ja kutsekoolide kaupa. Kooliastmete puhul on andmed kättesaadavad ainult põhiharidusega ja põhihariduseta madala haridustasemega 18-24aastaste noorte kohta, kes ei jätka õpinguid. ETU (2017) kohaselt on alates 2010. aastast olnud varakult haridussüsteemist lahkunud noorte seas põhihariduseta isikuid $10-12 \%$, v.a 2015. aastal, kui nende osakaal vähenes 
esimest korda ligikaudu 8\%-ni. Sealjuures oli ajavahemikul 2002-2009 varakult haridussüsteemist lahkunud isikute hulgas enim põhihariduseta noori ja seda üle 15\% (v.a aastal 2005, kui see näitaja oli umbes 10\%) (ibid.). See tähendab, et ligikaudu 90\% varakult haridussüsteemist lahkunud isikutest katkestab haridustee kas üleminekul põhikoolist gümnaasiumi, keskhariduse omandamise käigus või omandavad kutsehariduse ilma keskhariduseta. Rõhutamist väärib ka asjaolu, et 5-10 aastat pärast põhihariduse omandamist ei ole iga viies noor Eestis keskharidust omandanud (Valk, 2016). Seega, mida kauem on madala haridustasemega noored haridussüsteemist eemal, seda ebatõenäolisemaks muutub nende jaoks õpingutega jätkamine.

Üldine ettekujutus, mis kooliastmetes ja ôppetasemetel haridusteed enim katkestatakse, on võimalik saada, kui tugineda EHISe andmetele ning vaadata õppetöö katkestajate ja koolist väljalangemise määrasid. Üldhariduskoolides katkestatakse õpinguid enim põhikooli kolmandas astmes (ligikaudu 0,5\% noortest) ja gümnaasiumi esimesel aastal (ligikaudu 1\% noortest) (EHIS, 2017b). 2015. aastal oli üldharidusõppes 2357 õpingute katkestajat, kellest $49 \%$ oli mees- ja $51 \%$ naissoost ning $75 \%$-l oli emakeeleks eesti, $20 \%-1$ vene ja 5\%-1 muu keel (Statistikaamet, 2017). Sarnane trend on olnud ka varasematel aastatel, kus ligikaudu 2/3-l väljalangejate emakeeleks on eesti keel. Samas on noormehi olnud üldiselt rohkem. Kooliastmete järgi katkestasid 2015. aastal $79 \%$ väljalangenutest oma õpingud gümnaasiumis, $19 \%$ 7.-9. klassis ja $2 \%$ 1.-6. klassis (ibid.). Ka siin võib täheldada sarnast suundumust võrreldes varasemate aastatega.

Kutsehariduses on ajavahemikul 2000-2015 näidanud väljalangenud isikute arv iga aasta üldiselt kasvutrendi, v.a 2015. aastal, kus nende hulk vähenes 2014. aastaga võrreldes oluliselt (6408-lt 4847-ni) (Statistikaamet, 2017). Kutsekoolides katkestavad mehed naistest sagedamini õpingud ning pea iga viies meessoost isik kuulub katkestajate hulka. Kusjuures õpinguid katkestatakse enim esimesel õppeaastal ning iga järgmise õppeaastaga väheneb katkestajate arv märgatavalt (Valk, 2016).

\section{Sotsiaaldemograafilised erinevused}

Eurostati (2017) tööjõu-uuringu andmetest ilmneb, et Eestis on nendel 18-24aastastel noortel, kelle elukoht asub maa-asulates (alevikes ja külades), oluliselt suurem tõenäosus kujuneda varakult haridussüsteemist lahkujaks kui linnalistes asulates (linnades, vallasisestes linnades ja alevites) elavatel isikutel (vt tabel 1). 2015. aastal olid need näitajad Eestis vastavalt 16,8\% ja 4,9\% ${ }^{3 *}$.

Väikse usaldusväärsusega. 
Võrreldes teiste liikmesriikidega on Eestis maa-asulates elamine ka palju suurem varakult haridussüsteemist lahkumise riskitegur. Veelgi suurem on maaasulates elavate varakult haridussüsteemist lahkunud noorte osakaal vaid Bulgaarias (29,4\%), Rumeenias (27,8\%), Hispaanias (24,6\%) ja Portugalis (17,3\%). Seevastu Austrias (4,1\%), Tšehhis (5,5\%) ja Poolas $(6,1 \%)$ on alevikes ning külades elavate varakult haridussüsteemist lahkunud noorte osakaal väikseim.

Tabel 1. Varakult haridussüsteemist lahkunud noored Eestis elukoha ja soo järgi aastatel 2000-2015 (osatähtsus 18-24aastaste hulgas \%, Eurostat, 2017, edat_ Ifse_30)

\begin{tabular}{l|l|c|c|c|c|c|c|c|c|c|c|c}
\hline & & 2000 & 2002 & 2004 & 2006 & 2008 & 2010 & 2011 & 2012 & 2013 & 2014 & 2015 \\
\hline $\begin{array}{l}\text { Linnaline } \\
\text { asula }\end{array}$ & Kõik & - & - & - & 9 & 11,6 & 8,1 & 9,1 & 7,6 & $4,6^{*}$ & $4,7^{*}$ & $4,9^{*}$ \\
\cline { 2 - 12 } & Mehed & - & - & - & 13 & 16,7 & 11,2 & 9,7 & $10^{*}$ & $5,4^{*}$ & $6,4^{*}$ & $5,9^{*}$ \\
\cline { 2 - 12 } & Naised & - & - & - & - & $6,8^{*}$ & $5,5^{*}$ & 8,5 & $5,4^{*}$ & - & - & - \\
\hline \multirow{2}{*}{$\begin{array}{l}\text { Maa- } \\
\text { asula }\end{array}$} & Kõik & 15,1 & 13,6 & 13,9 & 17,3 & 16,5 & 14,2 & 12,7 & 13,5 & 13,6 & 17,3 & 16,8 \\
\cline { 2 - 12 } & Mehed & 19,2 & 16,9 & 20 & 25 & 22,8 & 17,5 & 16,3 & 16,1 & 19,5 & 21,7 & 18 \\
\cline { 2 - 12 } & Naised & 11,1 & 10,3 & 7,9 & 9,1 & 9,7 & 10,2 & 8,8 & 10,7 & $6,8^{*}$ & 12,4 & 15,4 \\
\hline
\end{tabular}

Märkus. * - väikse usaldusväärsusega.

Tabelist nähtub, et peaaegu iga viies 18-24aastane noormees, kes elab alevikus või külas, piirdub põhihariduse või sellest madalama haridustasemega. Kui võtta arvesse tööhõive näitajaid, siis osalevad varakult haridussüsteemist lahkunud 18-24aastased noormehed, kes elavad maa-asulates, teiste liikmesriikide omadega võrreldes oluliselt enam tööturul (Eurostat, 2017).

2015. aastal oli maa-asulates elavatest 18-24aastastest põhiharidusega või sellest madalama haridustasemega noormeestest tööga hõivatud 12,8\% (ibid.). Võib eeldada, et alevikes ja külades elavate 18-24aastaste noormeeste jaoks on olnud tööturul osalemine eelistatud valik. Ka Muraka, Lepiku, Dsissi ja Rämmeri (2007) uuringust kutsekooliõpingute katkestamise põhjuste kohta ilmnes, et noormeeste jaoks oli üks õpingute katkestamise peapõhjuseid töötamise eelistamine õppimisele.

Kui vaadata varakult haridussüsteemist lahkunud isikuid soolise jaotuse järgi, siis on võimalik tabelist 2 näha, et 2015. aastal oli 18-24aastaste vanuserühmas varakult haridussüsteemist lahkunuid noormeeste arvestuses 13,2\% ja tütarlaste hulgas $9 \%$. Positiivseks võib pidada asjaolu, et noormeeste osakaal Eestis on alates 2010. aastast üldiselt vähenenud, kuid endiselt nähtub nii Statistikaameti kui ka Eurostati tööjõu-uuringutest, et varakult haridussüsteemist lahkujate seas on noormehi keskmiselt kaks korda enam kui tütarlapsi. 
Lisaks ilmneb Eurostati (2017) tööjõu-uuringu andmetest, et ehkki pea kõikides liikmesriikides kalduvad noormehed võrreldes tütarlastega enam haridusteed katkestama, on Eestis varakult haridussüsteemist lahkunud isikute seas noormehi ELi keskmisest tunduvalt rohkem. Märkimisväärne on ka asjaolu, et Eesti sarnaneb noormeeste suure osakaalu poolest riikidega, mille näitajad on kõige kehvemad, edestades ainult Hispaaniat, Lätit, Maltat, Itaaliat, Portugali ja Küprost.

Tabel 2. Varakult haridussüsteemist lahkunud noored Eestis ja 28s ELi liikmesriigis keskmiselt soolise jaotuse järgi aastatel 2000-2015 (osatähtsus 18-24aastaste hulgas \%, Eurostat, 2017,T2020_40)

\begin{tabular}{l|l|c|c|c|c|c|c|c|c|c|c|c}
\hline & & $\mathbf{2 0 0 0}$ & $\mathbf{2 0 0 2}$ & $\mathbf{2 0 0 4}$ & $\mathbf{2 0 0 6}$ & $\mathbf{2 0 0 8}$ & $\mathbf{2 0 1 0}$ & $\mathbf{2 0 1 1}$ & $\mathbf{2 0 1 2}$ & $\mathbf{2 0 1 3}$ & $\mathbf{2 0 1 4}$ & $\mathbf{2 0 1 5}$ \\
\hline \multirow{2}{*}{ Eesti } & Kõik & 15,1 & 13,6 & 13,8 & 13,4 & 14 & 11 & 10,6 & 10,3 & 9,7 & 11,4 & 11,2 \\
\cline { 2 - 12 } & Mehed & 19,2 & 16,9 & 20 & 19,5 & 19,8 & 14,4 & 12,8 & 13,3 & 13,6 & 15,3 & 13,2 \\
\cline { 2 - 12 } & Naised & 11,1 & 10,3 & 7,9 & 6,9 & 8,3 & 7,6 & 8,4 & 7,3 & 5,8 & 7,5 & 9 \\
\hline $\begin{array}{l}28 \text { ELi } \\
\text { liikmes- } \\
\text { riiki }\end{array}$ & Kõik & - & 17 & 16 & 15,3 & 14,7 & 13,9 & 13,4 & 12,7 & 11,9 & 11,2 & 11 \\
\cline { 2 - 12 } & Mehed & - & 19 & 18,3 & 17,4 & 16,6 & 15,8 & 15,3 & 14,5 & 13,6 & 12,8 & 12,4 \\
\cline { 2 - 11 } & Naised & - & 14,9 & 13,8 & 13,2 & 12,7 & 11,9 & 11,5 & 10,9 & 10,2 & 9,6 & 9,5 \\
\hline
\end{tabular}

Võimalike põhjustena, miks noormehi ohustab tütarlastest enam haridustee katkestamine, võib nimetada poiste väiksemat ópimotivatsiooni ja óppeedukust, samuti on neil raskem alluda kooli reeglitele ja distsipliinile (Naarits-Linn, Pettai, \& Proos, 2012). Muu hulgas tunnevad poisid võrreldes tüdrukutega koolis rohkem igavust ning võib eeldada, et tüdrukud suudavad haridussüsteemiga paremini kohaneda (Leino, Veisson, Ruus, \& Ots, 2007; Naarits-Linn et al., 2012).

Toetudes ELi riikide andmetele, võib sisserändaja ja etnilise vähemuse taust, ent ka põlvnemine perekonnast, kus on riigikeelest erinev emakeel, suurel määral soodustada varakult haridussüsteemist lahkumist. Liikmesriigiti kogutakse sisserändajate, vähemuste ning inimeste kodakondsuse ja emakeele kohta statistilisi andmeid erinevalt. Seetõttu puudub usaldusväärne võrreldav andmestik. Kuna meil pole täpset statistilist ülevaadet sisserändaja ja vähemuse taustaga haridustee katkestanud isikutest Eestis, siis võetakse siinkohal vaatluse alla sellised näitajad nagu rahvus ja kodakondsus.

Tabelist 3 nähtub, et 2015. aasta rahvuskoosseisu järgi oli Eestis 18-24aastaste vanuserühmas varakult haridussüsteemist lahkunuid eestlaste hulgas $12 \%$ ning mitte-eestlaste arvestuses $9,2 \%$. Kui alates 2010 . aastast on eestlaste osakaal mõnevõrra suurenenud (+0,7\%), siis mitte-eestlaste hulgas on samal 
ajavahemikul varakult haridussüsteemist lahkumise osakaal veidi vähenenud $(-0,9 \%)$. Olulisi erinevusi rühmade vahel ei esine. Tuginedes Statistikaameti andmetele, võib järeldada, et mõne muu riigi kodakondsus või kodakondsusetus on tugev varakult haridussüsteemist lahkumise riskitegur. Sealjuures kuulus aastatel 2003-2005, kus see näitaja oli vastavalt $29,1 \%, 29,3 \%$ ja $33,5 \%$, iga kolmas 18-24aastane noor varakult haridussüsteemist lahkunute hulka. Aastatel 2006-2010 oli sama vanuserühma seas mõne muu riigi kodakondsusega või kodakondsuseta varakult haridussüsteemist lahkunud noorte osakaal vahemikus $18,9-26,3 \%$. Seega, iga neljas või viies mõne muu riigi kodakondsusega või kodakondsuseta 18-24aastane noor piirdus põhihariduse või sellest madalama haridusega. Ka ajavahemikus 2011-2013 olid selle rühma näitajad märkimisväärselt suured.

Tabel 3. Varakult haridussüsteemist lahkunud noored Eestis rahvuse ja kodakondsuse järgi aastatel 2000-2015 (osatähtsus 18-24aastaste hulgas \%, Eurostat, 2017, LES37 ja LES38)

\begin{tabular}{l|c|c|c|c|c|c|c|c|c|c|c}
\hline & $\mathbf{2 0 0 0}$ & $\mathbf{2 0 0 2}$ & $\mathbf{2 0 0 4}$ & $\mathbf{2 0 0 6}$ & $\mathbf{2 0 0 8}$ & $\mathbf{2 0 1 0}$ & $\mathbf{2 0 1 1}$ & $\mathbf{2 0 1 2}$ & $\mathbf{2 0 1 3}$ & $\mathbf{2 0 1 4}$ & $\mathbf{2 0 1 5}$ \\
\hline Kokku & 20,4 & 16,6 & 17,2 & 15,2 & 15,5 & 11,5 & 11,2 & 10,9 & 10,7 & 12,1 & 12 \\
\hline Eestlased & 21,6 & 15,9 & 15 & 16,6 & 15,9 & 12,1 & 11,2 & 11,7 & 11 & 13 & 12,8 \\
\hline Mitte-eestlased & 18,2 & 18,3 & 21,6 & 11,9 & 14,4 & 10,1 & 11,1 & 8,8 & 9,9 & 9,3 & 9,2 \\
\hline $\begin{array}{l}\text { Eesti } \\
\text { kodakondsus }\end{array}$ & 19,7 & 15,2 & 14,8 & 14,8 & 14,4 & 10,6 & 10,8 & 11,1 & 10,3 & 12,2 & 12 \\
\hline $\begin{array}{l}\text { Mõne muu riigi } \\
\text { kodakondsus või } \\
\text { kodakondsusetus }\end{array}$ & 23,1 & 24,2 & 29,3 & 18,9 & 23,8 & 21 & 14,7 & 9,4 & 15,2 & - & - \\
\hline
\end{tabular}

\section{Sotsiaal-majanduslik taust}

Kuigi ELis peetakse ebasoodsat sotsiaal-majanduslikku tausta üheks peamiseks varakult haridussüsteemist lahkumise riskiteguriks, siis Eesti noorte edu või ebaedu koolis mõjutab sotsiaal-majanduslik taust vähem kui enamikus teistes liikmesriikides (European Commission et al., 2014). Samuti on PISA testide põhjal ilmnenud, et õpilase sotsiaal-majanduslik taust avaldab Eesti õpilaste tulemustele vähem mõju kui enamikus teistes riikides (OECD, 2007, 2010b, 2013). Ka Eesti õpilaste haridustee katkestamisele on majanduslikul kihistumisel, koolide sotsiaal-majanduslikul segregatsioonil ning klassi kordama jätmisel võrreldes teiste liikmesriikidega suhteliselt vähene mõju (European Commission et al., 2014). 
Eurostati tulemustest ilmneb, et põhiharidusega või sellest madalama haridusega 18-24aastastel noortel on nii Eestis kui ka teistes liikmesriikides oluliselt suurem võimalus elada sotsiaalse tõrjutuse või vaesusohus kui kesk- ja kõrgharidusega samaealistel isikutel (vt tabel 4). 2015. aastal elas Eestis 22,4\% (ligikaudu 23 000) kõigist 18-24aastastest sotsiaalse tõrjutuse või vaesusohus (Eurostat, 2017). Sealjuures näitavad Eurostati andmed, et iga kolmas 18-24aastane noor, kes piirdub Eestis põhihariduse või sellest madalama haridusega, elab vaesusohus või on sotsiaalselt tõrjutud. 2015. aastal oli see näitaja $26,9 \%$ ning aastate jooksul on põhiharidusega või sellest madalama haridusega 18-24aastaseid isikuid juurde tulnud (ibid.). Samal ajal nähtub tabelist, et 2015. aastal olid samas vanuserühmas sotsiaalse tõrjutuse või vaesusohus 12,7\% kõrg-, 19,4\% kesk- ja 29,7\% põhihariduse või madalama haridusega inimestest. Seega, mida kõrgem on haridustase, seda väiksem on võimalus elada vaesusohus või olla sotsiaalselt tõrjutud.

Tabel 4. Sotsiaalse tõrjutuse või vaesusohus ${ }^{4}$ elavate $18-24$ aastaste noorte osakaal Eestis haridustaseme ja soo järgi aastatel 2004-2015 (\%, Eurostat, 2017, ilc_ peps04)

\begin{tabular}{l|l|c|c|c|c|c|c|c|c|c|c|c|c}
\hline & & $\mathbf{2 0 0 4}$ & $\mathbf{2 0 0 5}$ & $\mathbf{2 0 0 6}$ & $\mathbf{2 0 0 7}$ & $\mathbf{2 0 0 8}$ & $\mathbf{2 0 0 9}$ & $\mathbf{2 0 1 0}$ & $\mathbf{2 0 1 1}$ & $\mathbf{2 0 1 2}$ & $\mathbf{2 0 1 3}$ & $\mathbf{2 0 1 4}$ & $\mathbf{2 0 1 5}$ \\
\hline $\begin{array}{l}\text { ISCED } \\
\text { tase } \\
1-2\end{array}$ & Kõik & 35,8 & 36,5 & 26 & 27,7 & 22 & 24,3 & 29,6 & 34,2 & 33,8 & 33,2 & 30,3 & 29,7 \\
\cline { 2 - 14 } & Mehed & 34 & 38,8 & 23,2 & 28,1 & 19,3 & 25,4 & 30,4 & 33,5 & 32,5 & 33,9 & 31,2 & 29,7 \\
\hline & Naised & 38,6 & 32,8 & 29,8 & 27,1 & 25,7 & 22,7 & 28,5 & 35,2 & 35,7 & 32,2 & 29 & 29,6 \\
\hline $\begin{array}{l}\text { ISCED } \\
\text { tase } \\
3-4\end{array}$ & Kõik & 23,3 & 21,9 & 18,8 & 15,3 & 17,3 & 23 & 25,1 & 28,5 & 25,8 & 24,9 & 20,6 & 19,4 \\
\cline { 2 - 13 } & Mehed & 19,3 & 21,6 & 18,2 & 14,2 & 17,2 & 21,5 & 24,6 & 26,4 & 24 & 26 & 21,1 & 17,9 \\
\hline \multirow{2}{*}{$\begin{array}{l}\text { ISCED } \\
\text { tase } \\
5-8\end{array}$} & Kaised & 27,2 & 22,1 & 19,5 & 16,3 & 17,4 & 24,5 & 25,6 & 30,8 & 27,6 & 23,8 & 20,2 & 21 \\
\cline { 2 - 12 } & Mehed & 15,3 & 12,3 & 9,9 & 13,9 & 7 & 5,6 & 16,3 & 18 & 23,8 & 17,4 & 11,7 & 12,7 \\
\cline { 2 - 12 } & Naised & 15,5 & 12,8 & 12,7 & 15,9 & 3,7 & 7,7 & 18,3 & 19,7 & 23,2 & 17,7 & 10,4 & 9,8 \\
\hline
\end{tabular}

Kui võrrelda Eesti näitajaid teiste liikmesriikide omadega, siis selgub, et liikmesriikides avaldab madal haridustase 18-24aastaste hulgas oluliselt suuremat negatiivset mõju inimeste elukäigule kui Eestis. Eurostati andmetest ilmneb, et alates 2010. aastast satub ELis keskmiselt iga teine 18-24aastane isik, kes piirdub põhihariduse või sellest madalama haridusega, sotsiaalse tõrjutuse

4 Sotsiaalse tõrjutuse või vaesusohus elamine tähendab seda, et inimestel esineb vähemalt üks järgmistest tingimustest: väike sissetulek, tõsine materiaalne puudus või elamine väikse töökoormusega leibkonnas (vt Eurostat, 2016). 
või vaesusohtu (ibid.). Sealjuures elab üle 50\% Bulgaaria, Kreeka, Hispaania, Küprose, Portugali, Rumeenia, Itaalia ja Iirimaa madala haridustasemega 18-24aastastest noortest vaesusohus. Saksamaal, Eestis, Hollandis, Austrias, Luksemburgis, Sloveenias ja Soomes on see näitaja alla 30\%.

Eeltoodule lisaks ilmneb tabelist 5, et Eestis elas 2015. aastal suhtelises vaesuses ehk allpool suhtelise vaesuse piiri 17,6\% ja absoluutses vaesuses ehk allpool absoluutse vaesuse piiri 5,3\% 18-24aastaste vanuserühma kuuluvatest isikutest. Kogu Eesti elanikkonna vastavad näitajad olid 21,3\% ja 3,9\% (Statistikaamet, 2017). Tabelist nähtub, et alates 2010. aastast näitavad suhtelise ja absoluutse vaesuse määr vähenemistendentsi ning olulisi erinevusi meeste ja naiste vahel ei esine. Samas osutavad andmed, et viimaste aastate jooksul on ligikaudu iga viies 18-24aastaste vanuserühma kuulunud noor elanud suhtelises vaesuses. Materiaalset ilmajäetust koges 2015. aastal 10,3\% (u 10600 inimest) ning sügavat materiaalset ilmajäetust 2,9\% (u 3700) 18-24aastastest isikutest. Andmetest ilmneb, et noormehi ohustab nii materiaalne kui ka sügav materiaalne ilmajäetus tütarlastest enam. Ka materiaalse ilmajäetuse ja sügava materiaalse ilmajäetuse määrad on hakanud alates 2010. aastast vähenema.

Tabel 5. Vaesuse ja materiaalse ilmajäetuse määr 18-24aastaste vanuserühmas soo järgi aastatel 2004-2015 (\%, Statistikaamet, 2017, LES01)

\begin{tabular}{c|c|c|c|c|c|c|c|c|c|c|c|c|}
\hline & \multicolumn{3}{|c|}{$\begin{array}{c}\text { Suhtelise } \\
\text { vaesuse määr \% }\end{array}$} & \multicolumn{3}{c|}{$\begin{array}{c}\text { Absoluutse } \\
\text { vaesuse määr \% }\end{array}$} & \multicolumn{3}{c|}{$\begin{array}{c}\text { Materiaalse } \\
\text { ilmajäetuse määr \% }\end{array}$} & \multicolumn{3}{c}{$\begin{array}{c}\text { Sügava materiaalse } \\
\text { ilmajäetuse määr \% }\end{array}$} \\
\hline & Kokku & M & N & Kokku & M & N & Kokku & M & N & Kokku & M & N \\
\hline 2004 & 17,1 & 17,3 & 16,9 & 16 & 16,1 & 15,8 & 21,4 & 21,8 & 21,1 & 8,7 & 8,9 & 8,4 \\
\hline 2006 & 17,4 & 16,9 & 17,8 & 8 & 8,2 & 7,8 & 16,3 & 16,7 & 15,9 & 6,3 & 7 & 5,7 \\
\hline 2008 & 15,6 & 14,9 & 16,4 & 5,6 & 5,3 & 5,8 & 12,7 & 14,3 & 11 & 3,9 & 3,7 & 4,2 \\
\hline 2010 & 22,4 & 20,6 & 24,2 & 12,8 & 10,9 & 14,8 & 28,3 & 29,5 & 27,1 & 9,2 & 9,9 & 8,5 \\
\hline 2012 & 24,2 & 25,6 & 22,6 & 13,3 & 13,9 & 12,6 & 23,3 & 24,6 & 22 & 10,9 & 12,7 & 9,2 \\
\hline 2014 & 19,5 & 20 & 18,9 & 9,4 & 9,1 & 9,7 & 16,3 & 16,4 & 16,1 & 6,1 & 6,3 & 6 \\
\hline 2015 & 17,6 & 17 & 18,2 & 5,3 & 5,8 & 4,9 & 10,3 & 12,7 & 8 & 2,9 & 3,6 & 2,1 \\
\hline
\end{tabular}

Lisaks näitavad Statistikaameti andmed (tabel koodiga TT115), et mida kõrgem on 18-24aastaste noorte haridustase, seda suurem on nende osalus tööturul. Kui 2015. aastal töötas 30\% põhihariduse või sellest madalama haridusega (ISCED 1-2) sama vanuserühma noortest, siis järgmistes haridusastmetes (ISCED 3-4 ja ISCED 5-8) oli tööturul osalemise määr vastavalt 49,6\% ja 71,9\%. Sealjuures on alates 2010. aastast järjepidevalt suurenenud kõikide haridustasemete korral tööturul osalevate inimeste osakaal. 


\section{Varakult haridussüsteemist lahkumise mõjurid}

Individuaalseid, sotsiaalseid, hariduslikke ja kogukondlikke mõjureid on enim uurinud Byrne ja Smyth (2010), Kaye jt (2014, 2015), Lamote (2013), Lyche (2010), Rumberger (1995), Rumberger ja Lim (2008) ning Traag ja van der Velden (2008). Eestis on madala haridustasemega noorte temaatikat käsitlenud Aune Valk (2016), kes annab Haridus- ja Teadusministeeriumi aasta-analüüsis põhjaliku statistilise ülevaate hetkeolukorrast ning kirjeldab peamisi individuaalseid, kodu, kooli, sõprade ja eakaaslastega seotud mõjureid. Muu hulgas annab autor hea ülevaate meetmetest, mida Eestis rakendatakse madala haridustasemega noorte osakaalu vähendamiseks. Üldhariduskoolidest väljalangemise riskitegureid, mis on seotud indiviidi, kodu ja haridusega, on Eesti autoritest põhjalikumalt käsitlenud Kraav (2005), Kõiv (2007) ning Naarits-Linn jt (2012). Õpingute katkestamise põhjuseid kutseõppes on uurinud Espenberg, Beilmann, Rahnu, Reincke ja Themas (2012) ning Murakas jt (2007).

Varakult haridussüsteemist lahkumine on pikaajaline protsess (Lyche, 2010), mille korral saavad probleemid sageli alguse juba algklassides (Rumberger \& Lim, 2008). Kuigi varakult haridussüsteemist lahkumise põhjused on riigiti, ent ka piirkonniti väga erinevad, on võimalik siiski välja tuua peamised soodustavad mõjurid. Neid mõjureid võib Lyche (2010) järgi liigitada nelja rühma: 1) individuaalsed, 2) sotsiaalsed, 3) kooliga seotud ja 4) süsteemsed mõjurid (vt ka tabel 6).

Individuaalsetest ja sotsiaalsetest mõjuritest võib nimetada akadeemilist ebaedukust, mis on varakult haridussüsteemist lahkumise peamine riskitegur (Kõiv, 2007; Lamb, Walstab, Teese, Vichers, \& Rumberger, 2004; McCrone, Southcott, Featherstone, Macleod, \& Dawson, 2013; Rumberger, 1995; Rumberger \& Lamb, 2003; Traag \& van der Velden, 2008). Sealjuures selgus Valgu (2016) analüüsist, et keskhariduse omandamine sõltub Eestis suuresti põhikooli õpitulemustest ning ligi pool neist, kelle põhikooli lõputunnistuse keskmine hinne on alla 3,5, ei jõua keskhariduse omandamiseni. Seega mõjutavad õpilaste õpitulemusi nii nende akadeemiline võimekus kui ka kooli mikrokliima. Kitsingu, Tähe ja Kukemelgi (2015) uuring näitas, et õppurite alasoorituse taga võivad olla õpetajate vähesed ootused õpilaste suhtes, oskamatus arvestada õpilaste erivajadustega ning tahtepuudus õpilasi oma hoiakute pärast toetada.

Mitmed uuringud (McCrone et al., 2013; Spielhofer et al., 2009) on näidanud, et paljud haridustee katkestanud noored ei jätka õpinguid negatiivse õpikogemuse tõttu. Sageli on need noored olnud koolis vägivalla ja narrimise ohvrid (Spielhofer et al., 2009), neil on olnud konfliktsed suhted klassikaaslastega (Byrne \& Smyth, 2010; Walters \& Bowen, 1997) ning ópetajatega 
(Hawkins, Guo, Hill, Battin-Pearson, \& Abbott, 2001; Kaye et al., 2015; Kõiv, 2007; Murakas et al., 2007). Byrne’i ja Smythi (2010) uuringust selgus, et paljud varakult haridussüsteemist lahkujad kogesid õpingute ajal, et õpetajad suhtusid neisse negatiivselt, neid ei kuulatud ning peeti nõrgaks või probleemseks. Seevastu tugevad sotsiaalsed sidemed koolis (Hawkins et al., 2001) ja see, et õpilased tunnevad kuuluvust (nii akadeemiliselt kui ka sotsiaalselt) ning kogevad kooli toetust, aitavad neil kauem koolis püsida (Bond et al., 2007; Furrer \& Skinner, 2003).

Ka õpilase enda käitumisel võib olla otsene mõju haridustee katkestamisele. Nii õpilaste käitumisprobleemid koolis (Kõiv, 2007; Rumberger, 1995) kui ka suhtlemine antisotsiaalselt käituvate sõpradega (Battin-Pearson et al., 2000; Traag, Lubbers, \& van der Velden, 2012) soodustavad varakult haridussüsteemist lahkumist. Lisaks on alkoholi ja narkootikumide tarbijad suurema tõenäosusega varakult haridustee katkestajad (Battin-Pearson et al., 2000; Rumberger \& Lim, 2008). Kusjuures potentsiaalsed varakult haridussüsteemist lahkujad võivad tarbida psühhoaktiivseid aineid nii sotsiaalse surve tõttu kui ka selle pärast, et paremini toime tulla madala enesehinnangu, depressiooni, ärevuse või stressiga. Sage koolist puudumine (Kõiv, 2007; Lamb et al., 2004; Rumberger, 1995), väike õpimotivatsioon (Kõiv, 2007; Rumberger \& Lim, 2008; Traag \& van der Velden, 2008), vähene ambitsioon omandada haridust (Lamb et al., 2004), vähene osavõtt huvitegevustest (Mahoney \& Cairns, 1997), ent ka koolivahetus (Rumberger \& Lim, 2008) suurendavad samuti haridussüsteemist varakult lahkumise võimalust.

Varakult haridussüsteemist lahkunud noored on tihti madala enesehinnanguga (McCrone et al., 2013), neil esineb suhtlemisraskusi ning keskendumishäireid ja neil on puudulikud probleemilahendusoskused (Kõiv, 2007). Varakult haridussüsteemist lahkumise riskiteguriteks võib veel pidada halba tervist (Byrne \& Smyth, 2010; Murakas et al., 2007), füüsilist puuet, psüühilisi ja teisi erivajadusi (Rumberger \& Lim, 2008) või vajadust hoolitseda erivajadusega või terviseprobleemiga pereliikme eest (Lamb et al., 2004).

Varakult haridussüsteemist lahkumine on sageli seotud vanemate vaesuse, ebasoodsa sotsiaalse olukorra ja madala haridustasemega. Mida kõrgem haridustase on vanematel omandatud, seda väiksem on võimalus, et haridustee katkestatakse enneaegu (Rumberger \& Lamb, 2003; Traag \& van der Velden, 2008). Haridustee katkestamise riskiteguriteks võib muu hulgas pidada elamist üksikvanemaga peres (Espenberg et al., 2012; Traag \& van der Velden, 2008), pere sagedast kolimist (NESSE, 2010) ning vanemate välismaal töötamist (Valk, 2016). Varakult haridussüsteemist lahkumist soodustavad ka peresisesed konfliktid (Kõiv, 2007), lapsevanemate hoolimatu suhtumine nii lapsesse kui ka tema kooliskäimisse (Espenberg et al., 2012; Kaye et al., 2015; OECD, 2012) ning 
ebapiisav koostöö kooli ja kodu vahel (Rumberger \& Lim, 2008). Olukorras, kus noorel puudub vanematepoolne toetus, on haridusasutusel suur roll, mõjutamaks noore püsimist koolis.

Haridustee katkestanud noored on suurema tõenäosusega sisserändaja ja/või etnilise vähemuse taustaga (Kaye et al., 2015; Lyche, 2010; Rumberger, 1995). Neil on enamasti vaesem sotsiaal-majanduslik taust ning ebapiisav keeleoskus, et koolis edukalt hakkama saada. Väga tihti on haridustee katkestamine iseloomulik pigem noormeestele (Kraav, 2005; Naarits-Linn et al., 2012; Rumberger \& Lamb, 2003; Traag \& van der Velden, 2008). Võrreldes tütarlastega on poistel kehvemad õpitulemused, neil on raskem õpikeskkonnaga kohaneda ja nad omandavad harvemini keskhariduse (OECD, 2012).

Tööturu olukord avaldab samuti mõju noorte varajasele lahkumisele haridussüsteemist. Kui noorte jaoks on kättesaadavad madala palga ja staatusega töökohad, mis ei nõua kõrget haridus- ega oskuste taset, kuid võimaldavad noortel varakult raha teenida, siis on see paljude jaoks ajend siseneda tööjõuturule (European Commission, 2011). Espenbergi jt (2012) ja Muraka jt (2007) uuringute järgi katkestab väga suur hulk Eesti kutsekoolide õpilastest õpingud peamiselt vajadusest parandada perekonna majanduslikku olukorda.

Kooliga seotud mõjuritest soodustavad varakult haridussüsteemist lahkumist ebasoodne koolikliima (Kaye et al., 2015; Rumberger \& Lim, 2008), õppijakeskse hariduse puudumine, vähesed teadmised hariduslikest erivajadustest, tugisüsteemide ebapiisavus, puudulik karjäärinõustamine, ópilastele ebaoluliste ópetamismeetodite rakendamine (European Commission et al., 2014). Lisaks võivad noorte varakult haridussüsteemist lahkumist soodustada kooli ranged reeglid ja distsipliin, ebaõiglane hindamine (Kõiv, 2007; Rumberger, 1995) ning óppeasutuse vähene tugi (Espenberg et al., 2012; Murakas et al., 2007). Seega, koolides, kus õpilased tunnevad, et neid väärtustatakse, nad saavad vajalikku abi ja tuge ning neil on õpetajatega head suhted, väheneb võimalus, et haridustee katkestatakse enneaegu.

Süsteemsetest mõjuritest võib varakult haridussüsteemist lahkumise peamisteks teguriteks pidada klassi kordama jäämist (Rumberger \& Lim, 2008), koolide sotsiaal-majanduslikku segregatsiooni, varajast ópilaste kihistamist (OECD, 2012) ning kooli paiknemist maapiirkonnas või suurlinna ebasoodsa olukorraga piirkondades. Ka õpilastele mitteoluliste óppekavade rakendamisel (European Commission et al., 2014) on mõju haridustee katkestamisele. Lamesoo ja Aderi (2016) uuring näitab, et suur osa gümnasistidest Eestis ei taju vastutust oma õppimise eest ja gümnaasiumiõppe rolli oma eesmärkide saavutamisel. Samas rõhutatakse elukestva õppe strateegia (2014) raames rakendatava muutunud õpikäsituse korral vajadust õppija aktiivse osaluse ja vastutuse järele (vt ka Heidmets, 2017): „Kui õpilane ei võta gümnaasiumis 
oma õppimise eest vastutust, võib üks põhjustest olla selles, et põhikooli jooksul ei ole vajalikul määral pööratud tähelepanu vastutuse ja initsiatiivi kujundamisele õpilastes" (Lamesoo \& Ader, 2016, lk 45). Lisaks on gümnaasiumi riikliku õppekava (2011) järgi keskkooli üks põhiülesandeid luua tingimused, et õpilased omandaksid teadmised, oskused ja väärtushoiakud, mis võimaldaksid tõrgeteta jätkata õpiteed kõrgkoolis või gümnaasiumijärgses kutseõppes. „Gümnaasiumiastmes pakutavad valikkursused on üks vahend, mis peaks toetama noore kujunemist küpseks, valikuid teha oskavaks isiksuseks ning tagama, et noorte suundumine haridussüsteemist tööturule oleks võimalikult kiire ja sujuv" (Lamesoo \& Ader, 2016, lk 45). Samal ajal näitavad nii Kallipi (2016) kui ka Lamesoo ja Aderi (2016) uuringud, et gümnaasiumites pakutakse valikkursuste arvelt pigem kohustuslikke kursusi ning suur osakaal on nende ainete pakkumisel, mis toetavad riigieksamiks valmistumist.

Lyche (2010) esitab tabelis 6 toodud kokkuvõtva loendi varakult haridussüsteemist lahkumise mõjuriteguritest. Rõhutamist väärib asjaolu, et ELi tasandil on see liigitus võetud aluseks varakult haridussüsteemist lahkumise mõjurite uurimisel ja käsitlemisel.

Tabel 6. Varakult haridussüsteemist lahkumise mõjurid (Lyche, 2010)

\begin{tabular}{|c|c|c|c|}
\hline \multirow{10}{*}{$\begin{array}{l}\text { Individuaalsed/ } \\
\text { sotsiaalsed tegurid }\end{array}$} & \multicolumn{3}{|c|}{ Akadeemiline edukus } \\
\hline & \multirow[t]{3}{*}{ Käitumine } & \multirow[t]{2}{*}{ Kuuluvus } & Akadeemiline \\
\hline & & & Sotsiaalne \\
\hline & & \multicolumn{2}{|c|}{ Käitumisprobleemid } \\
\hline & \multirow[t]{6}{*}{ Taust } & \multicolumn{2}{|c|}{ Minevikukogemused } \\
\hline & & \multicolumn{2}{|l|}{ Tervis } \\
\hline & & \multirow[t]{4}{*}{ Perekond } & Struktuur \\
\hline & & & Harjumused \\
\hline & & & Demograafiline olukord \\
\hline & & & Ressursid \\
\hline \multirow[t]{2}{*}{ Kooliga seotud tegurid } & \multicolumn{3}{|c|}{ Kooli struktuur ja vahendid } \\
\hline & \multicolumn{3}{|c|}{ Kooli õppetegevus } \\
\hline Süsteemsed tegurid & & & \\
\hline
\end{tabular}




\section{Ennetus-, sekkumis- ja tagasitoomismeetmed}

Nii uurijad kui ka poliitikud on seisukohal, et varakult haridussüsteemist lahkumine kahjustab noorte karjääri kujunemist ning suurendab sotsiaalse tõrjutuse ja vaesusriski. Enne keskhariduse omandamist haridustee katkestanud noorte sissetulekud on keskmisest väiksemad (OECD, 2010a), nad töötavad enamasti ebakindlatel töökohtadel või osalise tööajaga (European Commission, 2011) ja sõltuvad sagedamini sotsiaalabist (NESSE, 2010). Varakult haridussüsteemist lahkunud noored on võrreldes eakaaslastega halvema tervisega (ibid.) ning neil esineb rohkem õigusrikkumisi (Traag et al., 2012). Suure tõenäosusega ei jätka varakult haridussüsteemist lahkunud isikud haridusteed (OECD, 2010a) ning osalevad vähe ka elukestvas õppes. Seega põhjustab haridussüsteemist varakult lahkumine suuri isiklikke, sotsiaalseid ja majanduslikke kulusid.

Kõikides liikmesriikides on kasutusel riikliku ja omavalitsuse tasandi meetmed ning strateegiad, mis aitavad vähendada varakult haridussüsteemist lahkunud noorte hulka. Belgias, Maltal, Hollandis, Austrias, Bulgaarias ja Hispaanias on hakatud rakendama ka programme, mis on välja töötatud haridussüsteemist varakult lahkunud noorte sihtrühmale (European Commission et al., 2014). Rõhutamist väärib asjaolu, et neis riikides on viimaste aastate jooksul oluliselt vähenenud haridustee katkestanute arv. Sealjuures on ELi riigid omavahel kokku leppinud, et varakult haridussüsteemist lahkumist vähendavad meetmed ja tegevused peaksid keskenduma nii ennetamisele, sekkumisele kui ka noorte tagasitoomisele haridussüsteemi ${ }^{5}$.

Varakult haridussüsteemist lahkunud noorte puhul on tegemist heterogeense rühmaga, mistõttu ei ole nende osakaalu võimalik vähendada vaid üksikute meetmete ning tegevuste abil. Siiski on liikmesriikide kogemuste põhjal ilmnenud kõige tõhusamad meetmed. Varakult haridussüsteemist lahkumise ennetamiseks peetakse ELi tasandil vajalikuks tagada kvaliteetne alusharidusja lapsehoiusüsteem. Euroopa Liidu 2020. aasta strateegia (European Commission, 2011) kohaselt peaks 2020. aastaks osalema alushariduses vähemalt 95\% lastest alates neljandast eluaastast kuni koolikohustusliku eani. Eestis käis 2015. aastal koolieelsetes lasteasutustes ligikaudu 91\% lastest (Statistikaamet, 2016) ning osalemine alushariduses näitab üldiselt kasvutrendi. Kvaliteetne ja kättesaadav alusharidus ning lapsehoid võimaldavad muu emakeelega lastel paremini ühiskonda integreeruda ning aitavad kaasa ebasoodsas olukorras olevate laste sotsiaalsele arengule ja paremate õpitulemuste saavutamisele. Uuringud on näidanud, et lasteaias käinud õpilased on kooliks paremini valmis

Varakult haridussüsteemist lahkumise vähendamiseks juba kavandatud ja tehtavatest tegevustest Eestis saab põhjaliku ülevaate Valgu (2016, lk 12) analüüsist ning Espenbergi jt (2012) uurimusest. 
ja paremate õpitulemustega (Rumberger \& Lim, 2008) ning suhtuvad kooliskäimisse positiivsemalt kui õpilased, kellel lasteaias käimise kogemus puudub (Apps, Mendolia, \& Walker, 2013).

Nii karjäärinõustamist kui ka ópiteede paindlikkuse suurendamist peetakse olulisteks ennetusmeetmeteks. Kuigi karjäärinõustamisteenus ei ole spetsiaalselt välja töötatud varakult haridussüsteemist lahkumise vähendamiseks, annab see suure panuse, et haridustee katkestamist ennetada. Ka Eestis on karjäärinõustamine meede, mis on mõeldud probleemide ennetamiseks nii üld- kui ka kutsehariduses. Eesti Uuringukeskuse (2014) karjääriõppe mõjususe uuringust selgus, et kuigi karjääri- ja nõustamisteenuseid pakutakse nii üld- kui ka kutsehariduses varasemast enam, erinevad koolid oluliselt karjääriplaneerimisinfo kättesaadavuse poolest.

Liialt jäigal õppekaval ja õppekorraldusel on otsene seos varakult haridussüsteemist lahkumisega. Sellest tulenevalt on liikmesriikides hakatud senisest enam tähelepanu pöörama paindlike ópiteede kujundamisele, mis aitaks sujuvalt siirduda ühest õppetasemest või kooliastmest teise (European Commission et al., 2014). Ka Eesti kutsekoolides tehtud uuringust (Murakas et al., 2007) selgus, et peamisteks võimalusteks vältida varajast lahkumist haridussüsteemist peeti tegevusi, mis olid seotud paindlikuma õppe pakkumisega, nagu näiteks kaugõppesse ülemineku võimalust, paindlikumat tunniplaani ning võimalust arvestada erialast töökogemust õpingute osana. Väga oluline ennetusmeede on ka varakult haridussüsteemist lahkumise teema põhjalik käsitlemine õpetajakoolituses. Kuna suure tõenäosusega on õpetajad esimesed, kes panevad tähele, kui õpilasel tekivad koolis probleemid, siis oskus neid varakult märgata ning õigel ajal sekkuda on hädavajalik. Seega on õpetajatel suur roll varakult haridussüsteemist lahkunud noorte osakaalu vähendamisel.

Oluliste ennetusmeetmetena võib nimetada veel klassikursuse kordama jätmise ja hariduse segregatsiooni vähendamist, diskrimineeritud gruppide (nt puudega isikute) paremat lõimimist ning õppekava- ja kooliväliste tegevuste korraldamist, nt võimalust tegelda koolis pärast õppetunde hobidega (European Commission et al., 2014).

Sekkumismeetmete seas on üks tõhusaimaid individuaalse toetuse pakkumine õpiraskustega ópilastele (ibid). Ka Naarits-Linni jt (2012) uuringust, mis korraldati üldhariduskoolides, selgus, et fookustatud, süsteemne ja vähemalt kogu õppeaasta kestev järjepidev tegevus koolist väljalangemise ohus oleva õpilasega annab häid tulemusi. Seejuures oli potentsiaalsete väljalangejate probleemidega tegelemisel koostöö tulemuslikum nende vanematega, kes olid kooliga aktiivses suhtluses 1. klassist peale ning kes osalesid kord aastas vanemate täiendkoolitusel ja lapse esinemistel (ibid.). 
Väga tõhusateks sekkumismeetmeteks loetakse ka keeleõppe pakkumist neile, kelle emakeel on riigikeelest erinev, suurema rõhu panemist kooli ja kodu koostöö tugevdamisele ning halvema ópisooritusega õpilaste toetamist. Rohkem kui pooltes liikmesriikides on kasutusel programmid, mis aitavad välja selgitada potentsiaalseid haridustee katkestajaid ja jälgida ópilaste puudumisi eesmärgiga identifitseerida väljalangemisohu märgid (European Commission et al., 2014). Samuti on olulisel kohal tugimeeskonna väljakoolitamine, et nad oskaksid aidata ja toetada nii potentsiaalseid varakult haridussüsteemist lahkujaid kui ka õpetajaid.

Sealjuures on varakult haridussüsteemist lahkunud noorte puhul ülioluline õigeaegne sekkumine. Õpilase õpi- ja käitumisprobleeme ning stressiilminguid on võimalik märgata enne haridustee reaalset katkestamist. Naarits-Linni jt (2012) uuringust selgus, et tõsised õpi- ja käitumisprobleemid tekivad enamasti alates 6. klassist. Kui aga probleeme märgatakse õigel ajal, siis on suurem võimalus, et õpilast suudetakse aidata ja ta jätkab õpingutega, lisaks kulub selleks vähem vahendeid (Cedefop, 2016).

Haridussüsteemi tagasitoomise meetmetena peetakse vajalikuks välja selgitada, kes kuuluvad varakult haridussüsteemist lahkunud isikute sekka, ning aidata neil haridussüsteemi tagasi pöörduda. Eestis on näiteks kutsekoolides võimalik õppida mõningatel erialadel ilma põhiharidust omamata. Siiski näitavad eri riikide kogemused, et kuigi ennetavate ja sekkuvate meetmete kasutamine on laialt levinud, on alles alates 2010. aastast suurenenud liikmesriikides nende meetmete osakaal, mis on mõeldud varakult haridussüsteemist lahkunud noorte tagasitoomiseks haridussüsteemi.

Võib öelda, et Eestis puuduvad spetsiaalselt varakult haridussüsteemist lahkunud noorte sihtrühmale välja töötatud üleüldised programmid. Küll aga on olemas nii riikliku, kohaliku omavalitsuse kui ka kooli tasandil universaalsed meetmed ja teenused, mida kasutatakse potentsiaalsete varakult haridussüsteemist lahkuvate õpilaste toetamiseks. Samas puudub nende meetmete tõhususe mõjuanalüüs. Seniste sekkumisviiside tõhususe hindamine annaks aluse muuta olemasolevaid tegevusi eesmärgipärasemaks, ent ka välja töötada õigeaegsed ja sihipärased tugimeetmed.

Kindlasti tuleks edaspidi suuremat rõhku panna karjääri- ja nõustamisteenuste pakkumise suurendamisele ning kvaliteedi parandamisele, ent ka varakult haridussüsteemist lahkumise teema põhjalikumale käsitlemisele õpetajakoolituses. Samuti vajab väljatöötamist seiresüsteem, mis võimaldaks õigel ajal identifitseerida potentsiaalsed varakult haridussüsteemist lahkujad. 


\section{Kokkuvõte}

Varakult haridussüsteemist lahkumine on Eesti jaoks endiselt tõsine probleem. Kuigi lahkujate absoluutarv on viimasel kümnendil vähenenud, oleme Euroopas jäänud kehva positsiooni. Eesti oli pikka aega nn keskmike grupis (koos Saksamaa, Iirimaa, Prantsusmaa, Soomega), kuid nüüd oleme langenud nende riikide hulka, kus haridustee katkestanute arv on kõige suurem. Seega konkureerime praegu Hispaania, Itaalia, Bulgaaria, Malta, Rumeenia ja Portugaliga. Sealjuures on neist ainult Eesti, Bulgaaria ja Rumeenia riigid, kes ei ole teinud võrreldes 2010. aastaga varakult haridussüsteemist lahkunud noorte osakaalu vähendamisel olulisi edusamme. Olukorras, kus rahvastik vananeb ning noorte arv väheneb, tähendab see Eesti jaoks suure hulga noorte potentsiaali ja võimaluste kasutamata jätmist. Tööturu ja ühiskonna ootustele mittevastav haridustase takistab püsiva ja hästi tasustatud töö leidmist, sellest johtuv ebakindlus ja kitsikus pärsivad omakorda nii perekonna loomist kui ka elus toimetulekut laiemalt.

Kõige suuremas väljalangemisohus on Eesti maakoolides õppivad poisid. Võib eeldada, et paljud neist on pärit majandusprobleemidega peredest, kus murede lahendusena nähakse noore kiiret tööle asumist. Haridussüsteemist lahkumise hinnaga saavutatud parem sissetulek on siiski vaid ajutine lahendus, pikaajalises perspektiivis pole see kindlasti jätkusuutlik.

Eesti kool seisab silmitsi keerulise ülesandega leida viis, kuidas hoida väljalangemisohus noori haridussüsteemis ja takistada nende varajast lahkumist. Liikumisel uue õpikäsituse suunas (vt Heidmets, 2017) on oluliseks eesmärgiks seatud iga õppuri individuaalse eripära ja perekondliku tagapõhja suurem arvestamine, et ühtaegu toetada andekaid ja teha tööd raskustes ópilastega. Väljalangemisohus noored on kindlasti sihtrühm, kelle puhul tuleb sellist lähenemisviisi rakendada. Muutunud õpikäsituse raames toimuv liikumine elulähedasema ning õpilaskesksema koolimudeli poole võiks just noormeeste jaoks kujuneda liimiks, mis neid kooliga rohkem seob ning huvi õppetöö vastu üleval hoiab. Huvitav kool tähendab ka paremat koolikliimat. Nagu selgus TALISe uuringust, mõjutab Eestis koolikliimat kooli asukoht: linnakoolides on õpetajate ja õpilaste suhted paremad (Loogma, Ruus, Talts, \& Poom-Valickis, 2009). Teades, et just ebaedu õpingutes on peamine põhjus, miks noored haridustee katkestavad, tuleb panustada nii õppetöö atraktiivsusesse kui ka positiivsetesse suhetesse õpetajate ja koolikaaslastega. Rumberger (1995) osutab, et ,... kuigi koolid ei saa teha midagi seoses oma õpilaste demograafiliste ja sotsiaalsete näitajatega, saavad nad muuta oma tegevusi, millel on otsene seos õppurite jäämisega kooli“ (lk 618). 
Praeguseks on meil olemas piisav teadmine, milliseid sihtrühmi varakult haridussüsteemist lahkumine ohustab. Seetõttu peaksid ka sekkumismeetmed olema sihtrühmaspetsiifilised. Maa-asulates elavatele noormeestele on vaja üht tüüpi meetmeid, edasijõudmatutele teistsuguseid, muu riigi kodakondsusega noortele kolmandaid. Ka 12. klassis haridustee katkestanud noor vajab teistsugust lähenemisviisi kui 7.-8. klassi õpilane. Fookuse suunamine kindlatele sihtrühmadele aitab paremini leevendada seda üht Eesti hariduse praegust murekohta.

\section{Tänusõnad}

Artikli valmimisele on kaasa aidanud TLÜ haridusinnovatsiooni keskus.

\section{Kasutatud kirjandus}

Apps, P., Mendolia, S., \& Walker, I. (2013). The impact of pre-school on adolescents' outcomes: Evidence from a recent English cohort. Economics of Education Review, 37, 183-199. https://doi.org/10.1016/j.econedurev.2013.09.006

Battin-Pearson, S., Newcomb, M. D., Abbott, R. D., Hill, K. G., Catalano, R. F., \& Hawkins, J. D. (2000). Predictors of early high school dropout: A test of five theories. Journal of Educational Psychology, 92(3), 568-592.

https://doi.org/10.1037/0022-0663.92.3.568

Bond, L., Butler, H., Thomas, L., Carlin, J., Glover, S., Bowes, G., \& Patton, G. (2007). Social and school connectedness in early secondary school as predictors of late teenage substance use, mental health, and academic outcomes. Journal of Adolescent Health, 40(4), 357.e9-e18. https://doi.org/10.1016/j.jadohealth.2006.10.013

Byrne, D., \& Smyth, E. (2010). No way back? The dynamics of early school leaving. Raheny: The Liffey Press.

Cedefop (2016). Leaving education early: Putting vocational education and training centre stage. Vol. 1: investigating causes and extent. Cedefop research paper No. 57. Luxembourg: Publications Office of the European Union.

Côté, J. E. (2000). Arrested adulthood: The changing nature of maturity and identity. New York: NYU Press.

Eesti elukestva õppe strateegia 2020 (2014). Tallinn: Haridus- ja Teadusministeerium. Külastatud aadressil https://www.hm.ee/sites/default/files/strateegia2020.pdf.

Eesti Uuringukeskus (2014). Karjääriõppe mõjususe uuring. Uuringu raport. Tallinn. Külastatud aadressil https://www.innove.ee/UserFiles/Haridustugiteenused/ Uuringud/Karj\%C3\%A4\%C3\%A4ri\%C3\%B5ppe\%20m\%C3\%B5jususe\% 20 uuring\%20(2014).pdf.

EHIS (2017a). EHIS-e andmebaas HaridusSilm. Põhikooli lõpetamine. Külastatud aadressil http://qlikview-pub.hm.ee/QvAJAXZfc/opendoc_hm.htm?document=htm_avalik. qvw\&host=QVS\%40qlikview-pub\&anonymous=true. 
EHIS (2017b). Statistilised tabelid. Külastatud aadressil http://www.hm.ee/ehis/statistika.html.

Espenberg, K., Beilmann, M., Rahnu, M., Reincke, E., \& Themas, E. (2012). Õpingute katkestamise põhjused kutseõppes. Tartu: Tartu Ülikooli sotsiaalteaduslike rakendusuuringute keskus RAKE.

European Commission (2011). Reducing early school leaving. Brussels: Commission Staff Working Paper.

European Commission, EACEA, Eurydice, \& Cedefop (2014). Tackling early leaving from education and training in Europe: Strategies, policies and measures. Eurydice and Cedefop Report. Luxembourg: Publications office of the European Union.

Eurostat (2016). Eurostat regional yearbook 2016. Luxembourg: Publications office of the European Union.

Eurostat (2017). Early leavers from education and training. Statistics. Retrieved from http://ec.europa.eu/eurostat/web/education-and-training/data/main-tables.

Furrer, C., \& Skinner, E. (2003). Sense of relatedness as a factor in children's academic engagement and performance. Journal of Educational Psychology, 95(1), 148-162. https://doi.org/10.1037/0022-0663.95.1.148

Gümnaasiumi riiklik õppekava (2011). Riigi Teataja I, 14.01.2011, 2. Külastatud aadressil https://www.riigiteataja.ee/akt/114012011002.

Hawkins, J. D., Guo, J., Hill, K. G., Battin-Pearson, S., \& Abbott, R. D. (2001). Longterm effects of the Seattle Social Development Intervention on school bonding trajectories. Applied Developmental Science, 5(4), 225-236.

https://doi.org/10.1207/S1532480XADS0504_04

Heidmets, M. (toim.) (2017). Õpikäsitus: teooriad, uurimused, mõõtmine. Analüütiline ülevaade. Tallinn: Tallinna Ülikool

Kallip, K. (2016). Valikkursuste pakkumisest gümnaasiumides. H. Voolaid (toim.), Ülevaade haridussüsteemi välishindamisest 2015/2016. óppeaastal (lk 68-74). Tartu: Haridus- ja Teadusministeerium.

Kaye, N., D’Angelo, A., Ryan, L., \& Lörinc, M. (2014). Early school leaving in the European Union: Data availability and reporting. RESL.eu project paper No. 3. Retrieved from https://www.uantwerpen.be/images/uantwerpen/container23160/files/Project\%20Paper\%203\%20-\%20final\%20version\%20online.pdf.

Kaye, N., D’Angelo, A., Ryan, L., \& Lőrinc, M. (2015). Students' survey (A1): Preliminary analysis. RESL.eu project paper No. 5. Retrieved from https://www.uantwerpen.be/images/uantwerpen/container23160/files/Project\%20Paper\%205_FinalVersion_Sep15(1).pdf.

Kitsing, M., Täht, K., \& Kukemelk, H. (2015). Kooli mikrokliima: õpetajate toetav käitumine ja õpilaste tulemuslikkus. Eesti Haridusteaduste Ajakiri, 3(1), 127-147. https://doi.org/10.12697/eha.2015.3.1.06

Kraav, I. (2005). Õpiedutus ja koolist väljalangemine kui sotsiaalse tõrjutuse eeldus ja tagajärg. I. Kraav (koost.), Õpiedutuse tekkepõhjused põhikoolis õpilaste, õpetajate ja lapsevanemate arvamuste põhjal (lk 7-22). Tartu: Ühiskondlik Pedagoogika Uurimise Instituut.

Kõiv, K. (2007). Koolist väljalangenute vaatenurk. Haridus, 11-12, 58-64.

Lamb, S., Walstab, A., Teese, R., Vickers, M., \& Rumberger, R. (2004). Staying on at school: Improving student retention in Australia. Melbourne: CPELL. 
Lamesoo, K., \& Ader, A. (2016). Muutunud õpikäsituse rakendamise ja selleks erinevate valikute pakkumise seire korraldamine, sh gümnaasiumis valikkursuste rakendamise osas. Projekti raport. Tartu Ülikool: Haridusuuenduskeskus.

Lamote, C. (2013). Less successful pathways through secondary school. Studies on grade retention and early school leaving (Doctoral dissertation). Leuven: Katholieke Universiteit Leuven.

Leino, M., Veisson, M., Ruus, V.-R., \& Ots, L. (2007). Mathematics, boys and girls in Estonia. In M. Chionidou-Moskofoglou, A. Blunk, R. Siemprinska, Y. Solomon, \& R. Tanzberger (Eds.), Promoting equity in maths achievement: The current discussion (pp. 119-139). Barcelona: Barcelona Technical University.

Loogma, K., Ruus, V-R., Talts, L., \& Poom-Valickis, K. (2009). Ópetaja professionaalsus ning tõhusama õpetamis- ja óppimiskeskkonna loomine. OECD rahvusvahelise ópetamise ja õppimise uuringu TALIS tulemused. Tallinn: Tallinna Ülikooli haridusuuringute keskus.

Lyche, C. S. (2010). Taking on the completion challenge: A literature review on policies to prevent dropout and early school leaving. OECD Education Working Papers No. 53. Paris: OECD Publishing. https://doi.org/10.1787/5km4m2t59cmr-en

Mahoney, J. L., \& Cairns, R. B. (1997). Do extracurricular activities against early school dropout? Developmental Psychology, 33(2), 241-253.

https://doi.org/10.1037/0012-1649.33.2.241

McCrone, T., Southcott, C., Featherstone, G., Macleod, S., \& Dawson, A. (2013). Research into training for young adults aged 19 to 24 who are not in education, employment or training (NEET). London: BIS.

Murakas, R., Lepik, A., Dsiss, H., \& Rämmer, A. (2007). Kutsekooliópingute katkemine ja taasalustamise võimalused. Ülevaade uurimistulemustest. Tartu: Tartu Ülikooli sotsioloogia ja sotsiaalpoliitika instituut.

Naarits-Linn, T., Pettai, I., \& Proos, I. (2012). Koolist väljalangemise ennetamine ópilase sotsiaalse toimetuleku tõstmise kaudu. Tallinn: MTÜ Mahena.

NESSE (2010). Early school leaving: Lessons from research for policy makers. Luxembourg: Publications Office of the European Union.

OECD (2007). PISA 2006: Science competencies for tomorrow's world (Vol. 1: Analysis). Paris: OECD Publishing.

OECD (2010a). Overcoming school failure: Policies that work. OECD project description. Retrieved from http://www.oecd.org/dataoecd/54/54/45171670.pdf.

OECD (2010b). PISA 2009 results: Overcoming social background. Equity in learning opportunities and outcomes (Vol. 2). Paris: OECD Publishing.

OECD (2012). Equity and quality in education: Supporting disadvantaged students and schools. Paris: OECD Publishing.

OECD (2013). PISA 2012 results: Excellence through equity. Giving every student the change to succeed (Vol. 2). Paris: OECD Publishing.

OECD (2016). Education at a glance 2016: OECD indicators. Paris: OECD Publishing.

Rumberger, R. W. (1995). Dropping out of middle school: A multilevel analysis of students and schools. American Educational Research Journal, 32(3), 583-625. https://doi.org/10.3102/00028312032003583

Rumberger, R. W., \& Lamb, S. P. (2003). The early employment and further education experiences of high school dropouts: A comparative study of the United 
States and Australia. Economics of Education Review, 22(4), 353-366.

https://doi.org/10.1016/S0272-7757(02)00038-9

Rumberger, R. W., \& Lim, S. A. (2008). Why students drop out of school: A review of 25 years of research. California Dropout Research Project Report No. 15. California: University of California.

Sotsiaalministeerium (2012). Töövaldkonna areng 2010-2011. Sotsiaalministeeriumi toimetised 2. Tallinn: Sotsiaalministeerium.

Spielhofer, T., Benton, T., Evans, K., Featherstone, G., Golden, S., Nelson, J., \& Smith, P. (2009). Increasing participation: Understanding young people who do not participate in education or training at 16 and 17. London: DCSF.

Statistikaamet (2016). Statistika andmebaas. Alusharidus. Tallinn: Statistikaamet. Külastatud aadressil http://pub.stat.ee/px-web.2001/Database/Sotsiaalelu/05Harid us/02Alusharidus/02Alusharidus.asp.

Statistikaamet (2017). Statistika andmebaas. Sotsiaalelu. Tallinn: Statistikaamet. Külastatud aadressil http://pub.stat.ee/px-web.2001/Database/Sotsiaalelu/databasetree.asp.

Traag, T., Lubbers, M. J., \& van der Velden, R. (2012). That's what friends are for? The impact of peer characteristics on early school-leaving. Maastricht: Maastricht Research School of Economics of Technology and Organizations.

Traag, T., \& van der Velden, R. K. W. (2008). Early school-leaving in the Netherlands: The role of student-, family- and school factors for early school-leaving in lower secondary education. Maastricht: Research Centre for Education and the Labour Market.

Vabariigi Valitsus (2013). Eesti noortevaldkonna arengukava 2014-2020. Tallinn.

Valk, A. (2016). Madala haridustasemega noored. Tartu: Haridus- ja Teadusministeerium.

Walters, K., \& Bowen, G. L. (1997). Peer group acceptance and academic performance among adolescents participating in a dropout prevention program. Child and Adolescent Social Work Journal, 14(6), 413-426. https://doi.org/10.1023/A:1024566930164 


\title{
Early leaving from education and training: trends, factors and measures in Estonia
}

\author{
Kadri Kallip ${ }^{1 a}$, Mati Heidmets ${ }^{\mathrm{a}}$ \\ ${ }^{a}$ School of Educational Sciences, Tallinn University
}

\begin{abstract}
Summary
The definition of "early leaver from education and training", previously "early school leaver", used at EU level refers to a young person aged between 18 and 24 who leaves education and training with only a lower secondary education or less, and who is not in further education or training (Eurostat, 2016). As demands for high skills and qualifications are growing, upper secondary education is considered to be the minimum qualification for a smooth transition to further levels of education and for a successful entry into the labour market (OECD, 2016).

The aim of the current article is to discuss the trends of early leaving from education and training (ELET) in Estonia during the period from 2000 to 2015 and to describe factors influencing early leaving, as well as measures for tackling or contributing to reducing ELET. The meta-analysis of the data from the European Labour Force Survey (LFS), Estonian Labour Force Survey, Estonian Education Information System (EHIS) and Estonian Statistics was performed. Though the rate of early leavers has decreased over the years in most EU countries (Eurostat, 2017), it is still a topic of great importance and relevance. Reducing its incidence to $10 \%$ by 2020 has been one of the five headline targets of Europe 2020 Strategy (European Commission, 2011). Estonia's national target is to reduce the share of early leavers to $9.5 \%$. At the same time, the rate of early leaving from education and training (ELET) in 2015 was $11.2 \%$ (EU-28 average was $11 \%)$. Compared with other member states, there are more early leavers only in Bulgaria, Hungary, Italy, Malta, Romania, Portugal and Spain.

Existing research and official data in the EU indicate that ELET is caused by individual, social, educational and systemic factors (Lyche, 2010) which interact with each other. It is typically more of a process than a single event and according to Rumberger and Lim (2008), for many pupils this process begins in early elementary school. Early leavers tend to work also more often in part-time or precarious jobs (European Commission, 2011), they earn less
\end{abstract}

School of Educational Sciences, Tallinn University, Narva mnt 25, 10120 Tallinn, Estonia; kadri.kallip@tlu.ee 
(OECD, 2010a), and more often are dependent on social assistance (NESSE, 2010). Early leavers from education and training are also less likely to take up further learning opportunities (OECD, 2010a), and thus participate less in lifelong learning.

In 2015, there were approximately 12,000 young persons aged between 18 and 24 in Estonia who left education with no more than a lower secondary education. Though the number of early leavers has dropped over the last decade, there are still too many pupils leaving school at different levels of education and at the school stage. Whereas. the overall share of early leavers fell in the EU Member States by 2.9 percentage points between 2010 and 2015, the proportion of early leavers in Estonia remained relatively unchanged (- 0.2 percentage points).

The results showed that from 2010 the proportion of early leavers without a lower secondary education ranged between $10 \%$ and $12 \%$. Thus, approximately $90 \%$ of the early leavers from education and training leave school during the transitions either from elementary to secondary school or during studies in upper secondary school. Whilst the number of persons in the age group 18 to 24 who participate in retraining, has decreased.

In terms of regions, a most early leavers from education and training are from the Central and Western Estonia and least in Northern Estonia. The results indicated that every fifth person aged from 18 to 24 from Järva, LääneViru or Rapla County and every sixth person of the same age group from Hiiu, Lääne, Pärnu or Saare County, left school early.

There is also evidence that living in a rural area is a very strong ELET predictor in Estonia. In 2015, there were $14.7 \%$ of those young people aged 18 to 24 who lived in rural areas and were considered as early leavers from education and training. Compared with other Member States, only Bulgaria, Romenia, Spain and Portugal have more early leavers from rural areas. The LFS statistics also showed that every fifth male person aged 18 to 24 living in rural area of Estonia is a early leaver from education and training. Whilst the rate of employed male leavers from rural areas is among the highest in the EU.

In most EU countries, boys are more likely to leave school prematurely than girls. In 2015 LFS statistics about Estonia showed that 13.2\% of males and 9\% of females in the 18-24 age category left school prematurely. Compared with other member states only Spain, Latvia, Malta, Italy, Portugal and Cyprus has a higher rate of male leavers than Estonia. It is also worth mentioning that those are the countries where the gap between girls and boys has been annually relatively high.

There is evidence that a low socio-economic background, as well as some aspects of education systems such as grade retention, socio-economic segregation 
and early tracking is identified as having a negative influence on the rates of early leaving (European Commission et al., 2014). However, those are the factors which have less impact on early leaving in Estonia than in other EU Member States. The results also showed that young people aged 18 to 24 with only a lower secondary education or less are more likely at risk of poverty or social exclusion and experience more relative and absolute poverty. At the same time, their rate of employment is also lower compared with persons with higher education levels in the same age group.

According to the Council of the EU there should be a comprehensive strategy to tackle early leaving, which should include prevention, intervention and compensation (re-integration) measures. Though there is no comprehensive ELET strategy in Estonia, there are policies and measures in place that can help in reducing ELET. One of the most effective measures in tackling early leaving has been improving access to high quality early childhood education and care (ECEC) and an education and career guidance system. Though many member states report that a guidance system has not been specifically developed to reduce the rate of early leavers, it has been an important support measure in combating ELET (European Commission, 2014). In Estonia, the participation rate in ECEC is high and a career guidance system is implemented at different educational levels. Nevertheless, different researches (Espenberg et al., 2012; Eesti Uuringukeskus, 2014) have showed that there is a need for implementing better quality career guidance systems more widely.

In tackling ELET, timely interventions are decisive. There is evidence that serious learning difficulties and behavioural problems appear after pupils begin their sixth-grade year (Naarits-Linn et al., 2012). Thus, if signs of stress and other problems are detected in time, there are more chances of retaining young people with relatively simple interventions, making it possible to get better results with fewer resources (Cedefop, 2016). According to Rumberger (1995, p. 618), "although schools cannot do anything about the demographic and social characteristics of their students, they can change their own practices that have a direct bearing on whether students remain in school". Creating open and supportive learning environments which focus on the needs of individual pupils can be the key element in tackling early school leaving.

Keywords: early leaving from education and training, school dropout, social demography, measures, international comparison, lifelong learning. 